\title{
ANALISA PERHITUNGAN DAN PELAPORAN PAJAK PENGHASILAN PASAL 21 PADA KOPERASI TELEKOMUNIKASI SELULAR (KISEL) SORONG
}

\author{
Markus Muda, SE \\ Jurusan Akuntansi Keuangan Publik \\ Politeknik Katolik Saint Paul Sorong \\ Email : markusmuda@gmail.com
}

\begin{abstract}
Abstrak
Penelitian ini bertujuan untuk mengetahui kesesuaian Perhitungan Pajak Penghasilan (PPh) Pasal 21 atas Pegawai Tetap pada Koperasi Telekomuikasi Selular (KISEL) Sorong dengan peraturan perpajakan yang berlaku secara umum. Dalam penelitian ini data dikumpulkan dengan metode wawancara dan studi pustaka.Jenis data yang terkumpul di analisis dengan metode deskriptif. Hasil analisis menunjukkan bahwa Perhitungan Pajak Penghasilan (PPh) Pasal 21 atas Pegawai Tetap pada Koperasi Telekomuikasi Selular (KISEL) Sorong masih terjadi kesalahan dan tidak sesuai dengan Undang-Undang No.36 Tahun 2008.
\end{abstract}

Kata Kunci : Pajak Penghasilan Pasal 21

\begin{abstract}
The main purpose of this study is to describe suitability the Calculation of Income Tax (PPh) of Article 21 on Employee on Koperasi Telekomunikasi Selular (KISEL) Sorong with tax laws applicable in general. In this study the data were collected by interview and literature. Types analysis showed that the Calculation of Income Tax (PPh) Article 21 on Employee Koperasi Telekomunikasi Selular (KISEL)Sorongis an eror and it is not in accordance with the Act No.36 of 2008.
\end{abstract}

Keywords: Income Tax Article 21

\section{PENDAHULUAN Latar Belakang}

Koperasi Telekomunikasi Selular (KISEL) Kota Sorong melakukan perhitungan, pemotongan, penyetoran, dan pelaporan pajak sehubungan dengan imbalan pekerjaan atau jasa atau kegiatan lain yang diterima wajib pajak yang dipotong atau dipungut pajak penghasilan diantaranya Pajak Penghasilan Pasal 21 atas pegawai tetap. Mengingat jumlah karyawan yang banyak, tingkat penghasilan, jabatan atau golongan serta status karyawan yang berbedabeda, maka dapat memungkinkan terjadinya kesalahan atau kekeliruan dalam melaksanakan perhitungan, pemotongan, penyetoran dan pelaporan pajak penghasilan.

Mencermati hal di atas, terlihat jelas begitu pentingnya cara penghitungan, pemotongan, pemyetoran, dan pelaporan pajak penghasilan pasal 21 yang baik dan benar atas pegawai tetap bagi perusahaan termasuk juga dalam hal pencatatan sebagai usaha menjalankan amanah kepercayaan yang diberikan negara kepada wajib pajak atas jenis penghasilan yang merupakan objek $\mathrm{PPh}$.

\section{Tujuan Penelitian}

Untuk menganalisa perhitungan dan pelaporan pajak penghasilan (PPH) pasal 21 yang menyangkut penghasilan karyawan tetap perusahaan dan juga untuk mengetahui kesesuaian antara perhitungan dan pelaporan pajak penghasilan karyawan Koperasi Telekomunikasi Selular (KISEL) Sorong dengan Undang-Undang No. 17 Tahun 2000 tentang pajak penghasilan yang berlaku di Indonesia.

\section{Manfaat Penelitian}

1. Praktis

a. Diharapkan dapat memberikan sumbangan atau masukkan bagi para pihak yang ingin mengetahui dan memahami tentang mekanisme perhitungan, pemotongan, penyetoran, dan pelaporan pajak penghasilan (PPH) pasal 21 yang menyangkut penghasilan karyawan tetap perusahaan, kususnya pada anggota Koperasi 
Telekomunikasi Selular (KISEL)Cabang Sorong.

b. Bermanfaat bagi masyarakat luas yang berkepentingan dalam memahami dan memperoleh gambaran yang jelas mengenai mekanisme perhitungan, pemotongan, penyetoran, dan pelaporan pajak penghasilan (PPH) pasal 21 yang menyangkut penghasilan karyawan tetap perusahaan.

\section{Teoritis}

Penelitian ini diharapkan dapat memberi manfaat secara teoritis yang berupa sumbangan bagi pengembangan ilmu pengetahuan dalam pelaksanaan perhitungan, pemotongan, penyetoran, dan pelaporan pajak penghasilan (PPH) pasal 21 yang menyangkut penghasilan karyawan tetap perusahaan.

\section{TINJAUAN PUSTAKA Dasar - Dasar Perpajakan}

Pajak merupakan iuran wajib dan pemungutannya didasarkan undang-undang sehingga pelaksanaannya dapat dipaksakan yang berarti bahwa barang siapa (wajib pajak) tidak atau tidak sepenuhnya memenuhi kewajiban perpajakannya sesuai dengan peraturan perundang-undangan perpajakan yang berlaku, terhadap mereka dapat dipaksa untuk memenuhi kewajiban tersebut melalui surat peringatan, surat teguran, dikenakan sanksi administrasi (bunga dan denda), termasuk penyitaan terhadap kekayaan wajib pajak, dan dapat dengan pidana penjara. Dengan demikian hukum pajak merupakan salah satu bagian dari hukum publik, yaitu hukum yang mengatur hubungan antara pemerintah selaku pemungut pajak dengan rakyatnya sebagai wajib pajak.

Menurut Prof. Dr. Rocmat Soemitro, dan Mardiasmo Pajak adalah iuran rakyat kepada kas negara berdasarkan Undang - Undang (yang dapat dipaksakan) dengan tiada mendapat jasa timbal balik (kontraprestasi) yang lansung dapat ditujukan dan yang digunakan untuk membayar pengeluaran umum".

Pajak penghasilan pasal 21 adalah pajak penghasilan yang di pungut sehubungan dengan pekerjaan, jasa dan kegiatan yang dilakukan oleh wajib pajak orang pribadi atas penghasilan berupa gaji, upah, honorarium, tunjangan, dan pembayaran lain dengan nama dan dalam bentuk apapun sehubungan dengan pekerjaan atau jabatan, jasa, dan kegiatan sebagaimana diatur dalam Undang-Undang nomor 17 Tahun 2000".

\section{Dasar Pengenaan, Pemotongan PPh Pasal 21}

Dasar pengenaan dan pemotongan $\mathrm{PPh}$ pasal 21 adalah sebagai berikut :

a. Penghasilan kena pajak, yang berlaku bagi :

1. Pegawai tetap, termasuk pejabat Negara, pegawai negeri sipil, anggota TNI/POLRI, pejabat Negara lainnya, pegawai badan usaha milik Negara dan badan usaha milik daerah, dan anggota dewan komisaris atau dewan pengawas, yang merangkap sebagai pegawai tetap pada perusahaan yang sama

2. Penerima pensiun berkala yang dibayarkan secara bulanan

3. Pegawai tidak tetap atau tenaga kerja lepas yang dibayarkan secara bulanan atau jumlah kumulatif penghasilan yang diterima dalam 1 (satu) bulan kalender telah melebihi Rp. 2.025.000,00.

4. Bukan pegawai yang menerima atau memperoleh penghasilan sehubungan dengan pemberian jasa sebagaimana yang dimaksud dalam pengertian wajib pajak huruf c yang menerima imbalan yang bersifat berkesinambungan.

b. Jumlah penghasilan yang melebihi Rp 200.000,00 (dua rarus ribu rupiah) sehari, yang belaku bagi pegawai tidak tetap atau tenaga kerja lepas yang menerima upah harian, upah mingguan, upah satuan atau upah borongan, sepanjang penghasilan kumulatif yang diterima dalam 1 (satu) bulan kalender belum melebihi Rp 2.025.000,00.

c. $50 \%$ (lima puluh persen) dari jumlah penghasilan bruto, yang berlaku bagi bukan pegawai sebagaimana dimaksud dalam pengertian wajib pajak huruf c.

d. Jumlah penghasilan bruto yang berlaku bagi penerima penghasilan seain penerima penhasilan sebagaimana yang dimaksud dalam pengertian wajib pajak huruf a, b, dan c.

\section{Penghasilan Kena Pajak} berikut :

Penghasilan kena pajak dihitung sebagai

Bagi pegawai tetap : 


$$
\begin{aligned}
\mathrm{PPh} \text { pasal } 21= & (\text { penghasilan neto }-\mathrm{PTKP}) \mathrm{x} \\
& \text { tariff pasal UU PPh } \\
= & (\text { penghasilan bruto }- \text { biaya } \\
& \text { jabatan }- \text { iuran pension dan } \\
& \text { iuran THT/JHT yang dibayar } \\
& \text { sendiri }-\mathrm{PTKP}) \times \text { tariff pasal } 17 \\
& \text { UU PPh }
\end{aligned}
$$

\section{Penghasilan Neto}

Besarnya penghasilan neto yang dipotong $\mathrm{PPh}$ pasal 21 adalah jumlah seluruh penghasilan bruto dikurangi biaya jabatan dari iuran pension.

\section{Penghasilan Tidak Kena Pajak (PTKP)}

Penghasilan tidak kena pajak (PTKP) pada dasarnya merupakan suatu bentuk keadilan dalam pajak dimana masyarakat atau penduduk dikenakan pajak sesuai dengan kemampuannya (ability to pay).Dengan ditetapkannya PTKP maka masyarakat yang berpenghasilan rendah/ dibawah PTKP tidak dikenakan pajak.Ketentuan PTKP sebagaimana diatur pasal 7 UU No. 36 Tahun 2008 anatara lain sebagai berikut.

a. Besarnya PTKP ditentukan dari keadaan pada awal tahun pajak atau awal bagian tahun pajak.

b. Penyesuaian besarnya penghasilan tidak kena pajak ditetapkan dengan peraturan Menteri Keuangan setelah konsultasi dengan Dewan Perwakilan Rakyat (DPR).

PTKP mengalami perubahan dari awal waktu ke waktu sesuai dengan perkembangan ekonomi dan social. Sebelum disesuaikan, PTKP berlaku per tanggal 1 januari 2014 sampai dengan 31 desember 2014 menurut Undang- Undang Pajak Penghasilan no. 36 Tahun 2008 adalah sebagai berikut :

a. Rp 24.300.000,00 (dua puluh emapat juta tiga ratus ribu rupiah) tambahan untuk wajib pajak orang peribadi

b. Rp 2.025.000,00 (dua juta dua puluh lima ribu rupiah) tambahan untuk seorang istri yang penghasilannya digabung dengan penghasilan suamiRp 24.300.000,00 (dua puluh emapat juta tiga ratus ribu rupiah) tambahan untuk seorang istri yang penghasilannya di gabung denga penghasilan suamiRp 2.025.000,00 (dua juta dua puluh lima ribu rupiah) tambahan untuk setiap anggota keluarga sedarah dalam garis keturunan lurus serta anak angkat, yang menjadi tanggungan sepenuhnya, paling banyak 3 (tiga) orang untuk setiap keluarga.

\section{Tarif PPh Pasal 21}

Tarif yang dipakai adalah tariff berdasarka pasal 17 ayat (1) Undang-Undang no.36 Tahun 2008.Tarif PPh Pasal 21 adalah tarif pajak progresif. Tarif $\mathrm{PPh}$ pasal 21 menurut Undang-Undang Pajak Penghasilan No. 36 Tahun 2008 yang berlaku per 1 januari 2009 untuk wajib pajak orang peribadi dalam negeri adalah :

Tabel. Penghasilan Kena Pajak

\begin{tabular}{|l|c|}
\hline Lapisan Penghasilan Kena Pajak & $\begin{array}{c}\text { Tarif } \\
\text { Pajak }\end{array}$ \\
\hline 0 Sampai dengan Rp 50.000.000,00 & $5 \%$ \\
\hline $\begin{array}{l}\text { Di atas Rp 50.000.000,00 s.d. Rp } \\
\text { 250.000.000,00 }\end{array}$ & $15 \%$ \\
\hline $\begin{array}{l}\text { Di atas Rp 250.000.000,00 s.d. Rp } \\
\text { 500.000.000,00 }\end{array}$ & $25 \%$ \\
\hline Di atas Rp 500.000.000,00 & 30 \\
\hline
\end{tabular}

\section{Surat Setoran Pajak}

Surat setoran pajak yang selanjutnya disebut SSP adalah bukti pembayaran atau penyetoran pajak yang telah dilakukan dengan menggunakan formulir atau telah dilakukan dengan cara lain ke kas Negara melalui tempat pembayaran yang ditunjuk oleh Menteri Keuangan.

Formulir SSP dibuat dalam rangka 4 (empat), dengan peruntukan sebagai berikut.

Lembar ke-1 : untuk wajib pajak

Lembar ke-2 : untuk kantor pelayanan perbendaharaan Negara (KPPN)

Lembar ke-3 : : untuk dilaporkan oleh wajib pajak ke kantor pelayanan Pajak

Lembar ke-4 : : untuk arsip kantor penerima pembayaran.

Dalam hal diperlukan, SSP dapat dibuat dalam rangkap 5 (lima) dengan peruntukan lembar ke-5 untuk wajib pungut (bendahara pemerintah/BUMN) atau pihak lain sesuai ketentuan perpajakan yang berlaku.

Satu formulir SSP hanya dapat digunakan untuk pembayaran satu jenis pajak dan satu masa pajak atau satu tahu pajak/ surat ketetapan pajak/ surat tagihan pajak dengan menggunakan satu kode akun pajak dan satu kode jenis setoran, kecuali wajib pajak dengan kriteria tertentu dapat membayar pajak penghasilan pasal 25 untuk beberapa masa pajak dalam satu SSP ( UU No. 16 Tahun 2009 tentang ketentuan umum dan tatacara perpajakan). 


\section{Surat Pemberitahuan (SPT)}

Surat pemberitahuan (SPT) mempunyai fungsi sebagai sarana bagi wajib pajak sendiri maupun pihak pemotong/ pemungut pajak menurut Undangundang dalam melapokan pembeyaran atau pelunasan pajak yang terutang, ataupun sebagai sarana dalam mempertanggungjawabkan perhitungan jumlah pajak yang terhutang. ${ }^{8}$ SPT dibedakan menjadi 2 (dua) yaitu :

1. SPT Masa, yaitu SPT yang digunakan untuk melakukan pelaporan atas pembayaran pajak bulanan.

2. SPT Tahunan, yaitu SPT yang digunakan untuk melakukan pelaporan atas pembayaran pajak tahunan.

Batas waktu pelaporan SPT Masa adalah tanggal 20 bulan berikutnya (PMK.No 80/PMK.03/2010). Keterlambatan pelaporan untuk SPT Masa PPh pasal 21 dikenakan denda sebesar Rp 100.000,00 (seratus ribu rupiah).

Pelaporan pajak disampaikan ke kantor pelayanan pajak (KPP) atau kantor pelayanan, penyuluhan, dan konsultasi pajak (KP2P) dimana wajib pajak terdaftar.

\section{Perhitungan PPH Pasal 21}

Berikut contoh perhitungan $\mathrm{PPh}$ Pasal 21 yang diatur dalam Undang - Undang No. 36 Tahun 2008 :

1. Budi adalah seorang pegawai tetap pada suatu perusahaan, belum menikah dan memperoleh gaji sebulan Rp. 3.000.000,00. Budi membayar Iuran Hari Tua setiap bulannya sebesar 2,00\% dari gaji dan membayar iuran pensiun sebesar $1,00 \%$ dari gaji setiap bulannya. Pada bulan juli 2014 budi menerima pembayaran berupa gaji dan bonus bulanan sabesar Rp. 500.000,00. Perhitungan PPh Pasal 21 bulan juli 2014 adalah sebagai berikut :

\begin{tabular}{|c|c|}
\hline Gaji & Rp. $3.000 .000,00$ \\
\hline Bonus Bulanan & Rp. $\quad 500.000,00$ \\
\hline Penghasilan Bruto & Rp. $3.500 .000,00$ \\
\hline \multicolumn{2}{|l|}{ Pengurangan : } \\
\hline \multicolumn{2}{|l|}{ 1. Biaya Jabatan } \\
\hline $5 \% \times 3.500 .000,00$ & Rp. $175.000,00$ \\
\hline 2. Iuran Pensiun & Rp. $30.000,00$ \\
\hline \multicolumn{2}{|c|}{ 3. Iuran Jaminan Hari TuaRp. $60.000,00$} \\
\hline \multicolumn{2}{|c|}{ Rp. $265.000,00$} \\
\hline Penghasilan Neto S & Rp 3.235.000,00 \\
\hline
\end{tabular}

12 x Rp. $3.235 .000,00 \quad$ Rp. $38.820 .000,00$

PTKP

- Untuk WP sendiri $\quad$ Rp. 24.300.000,00

Penghasilan kena pajak

Setahun

Rp. $24.300 .000,00$

PPh terutang :

5\% x Rp. 14.520.000,00 Rp. 726.000,00

PPh Pasal 21 bulan juli

Rp. $726.000,00: 12=\quad$ Rp. $60.500,00$

2. Yudi adalah seorang pegawai tetap pada suatu perusahaan, menikah tanpa anak, memperoleh gaji sebulan Rp. 3.000.000,00. Budi membayar Iuran Hari Tua setiap bulannya sebesar 2,00\% dari gaji dan membayar iuran pensiun sebesar $1,00 \%$ dari gaji setiap bulannya. Pada bulan juli 2014 budi menerima pembayaran berupa gaji dan bonus bulanan sabesar Rp. 500.000,00. Perhitungan PPh Pasal 21 bulan juli 2014 adalah sebagai berikut :

\begin{tabular}{|c|c|}
\hline Gaji & Rp. 3.000.000,00 \\
\hline Bonus Bulanan & Rp. $\quad 500.000,00$ \\
\hline Penghasilan Bruto & Rp. 3.500.000,00 \\
\hline \multicolumn{2}{|l|}{ Pengurangan : } \\
\hline \multicolumn{2}{|l|}{ 1. Biaya Jabatan } \\
\hline $5 \% \times 3.500 .000,00$ & Rp. $175.000,00$ \\
\hline 2. Iuran Pensiun & Rp. $30.000,00$ \\
\hline \multicolumn{2}{|c|}{ 3. Iuran Jaminan Hari TuaRp. $\quad 60.000,00$} \\
\hline & Rp.265.000,00 \\
\hline Penghasilan Neto Sebulan & $\operatorname{Rp} 3.235 .000,00$ \\
\hline \multicolumn{2}{|c|}{ Penghasilan Neto Setahun } \\
\hline 12 x Rp. $3.235 .000,00$ & Rp. 38.820.000,00 \\
\hline \multicolumn{2}{|l|}{ PTKP } \\
\hline - Untuk WP sendiri & Rp. 24.300.000,00 \\
\hline - Tambahan WP kawin & Rp $\quad 2.025 .000,00$ \\
\hline & Rp. 26.325.000,00 \\
\hline
\end{tabular}

Penghasilan kena pajak

Setahun Rp. 12.495.000,00

PPh terutang :

5\% x Rp. 12.495.000,00 Rp. 624.750,00

PPh Pasal 21 bulan juli

Rp. $624.750,00: 12=\quad$ Rp. $52.062,00$

3. Bimo adalah seorang pegawai tetap pada suatu perusahaan, menikah dan memiliki 3 anak, memperoleh gaji sebulan Rp. 3.000.000,00. Budi membayar Iuran Hari Tua setiap bulannya sebesar $2,00 \%$ dari gaji dan membayar iuran pensiun sebesar $1,00 \%$ dari gaji setiap bulannya. Pada bulan juli 2014 budi menerima pembayaran berupa gaji dan bonus bulanan sabesar Rp. 
500.000,00. Perhitungan PPh Pasal 21 bulan juli 2014 adalah sebagai berikut :

Gaji

Bonus Bulanan

Penghasilan Bruto

Pengurangan :

1. Biaya Jabatan

$5 \%$ x 3.500.000,00

Rp. $175.000,00$

2. Iuran Pensiun

Rp. $30.000,00$

3. Iuran Jaminan Hari TuaRp. $60.000,00$

Rp. $265.000,00$

Penghasilan Neto Sebulan Rp 3.235.000,00

Penghasilan Neto Setahun

12 x Rp. 3.235.000,00 Rp. 38.820.000,00

PTKP

- Untuk WP sendiri

Rp. $24.300 .000,00$

- Tambahan WP kawin

Rp 2.025.000,00

- $\mathrm{K}_{1}$

$-\mathrm{K}_{2}$

Rp. $2.025 .000,00$

Rp. $2.025 .000,00$

Rp. $2.025 .000,00$

Rp. $32.400 .000,00$

Penghasilan kena pajak

Setahun

Rp. $\quad 6.420 .000,00$

$\mathrm{PPh}$ terutang :

5\% x Rp. 6.420.000,00 Rp. $312.000,00$

PPh Pasal 21 bulan juli

Rp. $312.000,00: 12=\quad$ Rp. $26.750,00$

\section{METODE PENELITIAN Jenis Penelitian}

Penelitian ini merupakan penelitian yang menggunakan metode deskriptif dengan pendekatan kualitatif yang bertujuan untuk memberikan gambaran secara objektif tentang keadaan sebenarnya dari objek yang diteliti. Penelitian ini dilakukan dengan cara mendeskripsi masalah yang telah didefinisikan dan terbatas pada sejauh mana usaha untuk mengungkap masalah dan keadaan sebagaimana adanya, sehingga merupakan pengungkapan fakta-fakta yang ada.

\section{Jenis dan Sumber Data}

Jenis dan sumber data yang terhimpun dan hasil penelitian ini diperoleh melalui penelitian lapangan dan kepustakaan, digolongkan ke dalam 2 (dua) jenis data, yaitu:

1. Data Primer
Data primer adalah data yang diperoleh dan dikumpulkan dengan cara melakukan penelitian langsung pada Koperasi Telekomunikasi Selular (KISEL) Kota Sorong melalui wawancara dengan beberapa pihak yang ditunjuk oleh perusahaan untuk memotong pajak penghasilan pasal 21, guna mendapatkan data yang diperlukan yang berkaitan dengan masalah penelitian.

2. Data Sekunder

Data sekunder adalah data yang diperoleh dari laporan dan data perusahaan sepaerti SPT dan SSP, buku-buku, tulisan, surat edaran Direktur Jenderal Pajak, jurnal Perpajakan serta data dari perusahaan yang berhubungan dengan pemotongan pajak penghasilan, seperti :

a. Sejarah singkat perusahaan

b. Struktur organisasi perusahaan

c. Tugas dan fungsi setiap bagian dalam struktur organisasi

d. Pemotongan pajak penghasilan pasal 21

\section{Metode Pengumpulan Data}

Teknik pengumpulan data yang digunakan untuk memperoleh data dan informasi adalah sebagai berikut:

1. Interview (Wawancara)

2. Observasi langsung (studi lapangan)

3. Studi pustaka

4. Studi Dokumentasi

\section{Teknik Analisis Data}

Penelitian ini dalam menganalisis data secara deskriptif-kualitatif. Hal ini sejalan dengan pendapat Bogdan dan Taylor (1975) dalam Moleong (2013: 3) yang menyatakan "metodologi kualitatif" sebagai prosedur penelitian yang menghasilkan data deskriptif berupa kata-kata tertulis atau lisan dari orang-orang dan perilaku yang dapat diamati. Dengan kata lain, penelitian ini disebut penelitian kualitatif karena merupakan penelitian yang tidak mengadakan perhitungan. Dalam penelitian ini digunakan analisa kualitatif dengan menggunakan metode deduksi yaitu metode yang bertolak dari halhak yang bersifat umum ke hal-hal yang bersifat khusus. Hasil dari analisa kemudian disajikan secara deskriptif yaitu menjelaskan, menguraikan, dan menggambarkan sesuai dengan permasalahan secara mendalam yang erat kaitannya dengan penelitian ini. 


\section{PEMBAHASAN DAN HASIL}

Mekanisme Perhitungan Dan Pelaporan Pajak Penghasilan Pasal 21 Karyawan.

Mekanisme perhitungan PPh Pasal 21 atas pegawai tetap pada Koperasi Telekomunikasi Selular (KISEL) Cabang Sorong adalah sebagai berikut:

1. Perhitungan Pajak Penghasilan yang dipotong dari para karyawan diperoleh dengan menggunakan daftar gaji karyawan perusahaan yang berisi rincian masing-masing karyawan meliputi gaji pokok, tunjangan- tunjangan yang diperoleh karyawan.

2. Perusahaan mengelompokkan para karyawannya berdasarkan statusnya yaitu sudah kawin atau belum atau tidak kawin dan juga sudah punya anak atau tanggungan atau belum punya anak untuk membantu proses penetapan Pajak Penghasilan.

3. Pembayaran Pajak Penghasilan dilakukan setiap bulan dengan memotong penghasilan para karyawan.

4. Perusahaan menetapkan bahwa perusahaan menggunakan pembayaran pajak dengan cara bulanan atau menggunakan SPT Masa.

5. Perusahaan dalam menentukan pajak penghasilan menggunakan pembukuan dan hal ini ditandai dengan penggunaan laporan keuangan perusahaan dan daftar gaji para karyawan perusahaan.

Hasil penghitungan Pajak Penghasilan Pasal 21 yang harus dipotong untuk masing-masing pegawai di Koperasi Telkomsel (KiSel) Kota Sorong, selanjutnya dalam hal ini pemotong pajak yaitu Koperasi Telkomsel (KiSel) Kota Sorong harus menyetorkan pajak menggunakan Surat Setoran Pajak (SSP) yang terisi dengan benar, lengkap, dan jelas. Pajak Penghasilan Pasal 21 untuk setiap Masa Pajak wajib disetor ke Kontor Pos atau Bank Papua yang telah ditunjuk oleh Menteri Keuangan dan penyetoran pajak tidak lebih dari tanggai 10 (sepuluh) bulan berikutnya.Adapun data tersebut sebagaimana tersaji pada tabel berikut: 
Tabel 4.3

Contoh Perhitungan Pajak Pasal 21 Karyawan oleh Perusahaan Koperasi Telkomsel (KiSel) Kota Sorong

\begin{tabular}{|c|c|c|c|c|c|c|}
\hline Tahun & \multicolumn{3}{|c|}{2014} & \multicolumn{3}{|c|}{2015} \\
\hline Nama / Status & $\begin{array}{c}\text { Suwarto/ } \\
\text { TK }\end{array}$ & $\begin{array}{l}\text { Eko Retno } \\
\text { Diyah/ Ko }\end{array}$ & $\begin{array}{c}\text { Budi } \\
\text { Suwito/ } \mathbf{K}_{1}\end{array}$ & $\begin{array}{c}\text { Suwarto/ } \\
\text { TK }\end{array}$ & $\begin{array}{l}\text { Eko Retno } \\
\text { Diyah/ K0 }\end{array}$ & $\begin{array}{c}\text { Budi } \\
\text { Suwito/ } \mathbf{K}_{1}\end{array}$ \\
\hline $\begin{array}{l}\text { Gaji Pokok Per } \\
\text { Bulan }\end{array}$ & 3.750 .000 & 4.150 .000 & 7.155 .000 & 3.750 .000 & 4.150 .000 & 7.155 .000 \\
\hline $\begin{array}{l}\text { Gaji Pokok Per } \\
\text { Tahun }\end{array}$ & 45.000 .000 & 49.800 .000 & 85.860 .000 & 45.000 .000 & 49.800 .000 & 85.860 .000 \\
\hline Tunjangan Istri & - & 4.980 .000 & 8.586 .000 & - & 4.980 .000 & 8.586 .000 \\
\hline Tunjangan Anak & - & - & 2.575 .800 & - & - & 2.575 .800 \\
\hline $\begin{array}{l}\text { Jumlah Gaji dan } \\
\text { Tunjangan }\end{array}$ & 45.000 .000 & 54.780 .000 & 97.021 .800 & 45.000 .000 & 54.780 .000 & 97.021 .800 \\
\hline $\begin{array}{l}\text { Tunjangan } \\
\text { Perbaikan } \\
\text { Penghasilan } \\
\end{array}$ & 3.600 .000 & 4.308 .000 & 4.800 .000 & 3.600 .000 & 4.308 .000 & 4.800 .000 \\
\hline $\begin{array}{l}\text { Tunjangan } \\
\text { Struktural/Fungs } \\
\text { ional }\end{array}$ & 2.760 .000 & 3.600 .000 & 2.976 .480 & 2.760 .000 & 3.600 .000 & 2.976 .480 \\
\hline $\begin{array}{l}\text { Jumlah } \\
\text { Penghasilan } \\
\text { Bruto }\end{array}$ & 51.360 .000 & 62.688 .000 & 104.798 .280 & 51.360 .000 & 62.688 .000 & 104.798 .280 \\
\hline $\begin{array}{l}\text { Jumlah } \\
\text { Pengurang }\end{array}$ & - & - & - & - & - & - \\
\hline $\begin{array}{l}\text { Jumlah } \\
\text { Penghasilan } \\
\text { Neto } \\
\end{array}$ & 51.360 .000 & 62.688 .000 & 104.798 .280 & 51.360 .000 & 62.688 .000 & 104.798 .280 \\
\hline $\begin{array}{l}\text { Masa Perolehan } \\
\text { Penghasilan } \\
\text { (bulan) }\end{array}$ & 12 & 12 & 12 & 12 & 12 & 12 \\
\hline $\begin{array}{l}\text { Jumlah } \\
\text { Penghasilan } \\
\text { Neto Setahun } \\
\end{array}$ & 51.360 .000 & 62.688 .000 & 104.798 .280 & 51.360 .000 & 62.688 .000 & 104.798 .280 \\
\hline PTKP & 24.300 .000 & 24.300 .000 & 24.300 .000 & 36.000 .000 & 36.000 .000 & 36.000 .000 \\
\hline PKP & 27.060 .000 & 38.388 .000 & 80.498 .280 & 15.360 .000 & 26.688 .000 & 68.798 .280 \\
\hline PPh 21 Terutang & 112.750 & 159.950 & 355.409 & 64.000 & 111.200 & 286.659 \\
\hline
\end{tabular}

Sumber :Data Perhitungan PPh Pasal 21 Karyawan Koprasi Telekomunikasi Selular Sorong 2014 dan 2015(diolah) 
Tabel 4.4

Contoh Perhitungan Pajak Pasal 21 Karyawan Menurut Undang - Undang

\begin{tabular}{|c|c|c|c|c|c|c|}
\hline Tahun & \multicolumn{3}{|c|}{2014} & \multicolumn{3}{|c|}{2015} \\
\hline Nama / Status & $\begin{array}{c}\text { Suwarto/ } \\
\text { TK }\end{array}$ & $\begin{array}{c}\text { Eko Retno } \\
\text { Diyah/ K }\end{array}$ & $\begin{array}{c}\text { Budi } \\
\text { Suwito/ } K_{1}\end{array}$ & $\begin{array}{c}\text { Suwarto/ } \\
\text { TK }\end{array}$ & $\begin{array}{c}\text { Eko Retno } \\
\text { Diyah/ Ko }\end{array}$ & $\begin{array}{c}\text { Budi } \\
\text { Suwito/ } K_{1}\end{array}$ \\
\hline $\begin{array}{l}\text { Gaji Pokok Per } \\
\text { Bulan }\end{array}$ & 3.750 .000 & 4.150 .000 & 7.155 .000 & 3.750 .000 & 4.150 .000 & 7.155 .000 \\
\hline $\begin{array}{l}\text { Gaji Pokok Per } \\
\text { Tahun }\end{array}$ & 45.000 .000 & 49.800 .000 & 85.860 .000 & 45.000 .000 & 49.800 .000 & 85.860 .000 \\
\hline Tunjangan Istri & - & 4.980 .000 & 8.586 .000 & - & 4.980 .000 & 8.586 .000 \\
\hline Tunjangan Anak & - & - & 2.575 .800 & - & - & 2.575 .800 \\
\hline $\begin{array}{l}\text { Jumlah Gaji dan } \\
\text { Tunjangan }\end{array}$ & 45.000 .000 & 54.780 .000 & 97.021 .800 & 45.000 .000 & 54.780 .000 & 97.021 .800 \\
\hline $\begin{array}{l}\text { Tunjangan } \\
\text { Perbaikan } \\
\text { Penghasilan } \\
\end{array}$ & 3.600 .000 & 4.308 .000 & 4.800 .000 & 3.600 .000 & 4.308 .000 & 4.800 .000 \\
\hline $\begin{array}{l}\text { Tunjangan } \\
\text { Struktural/Fungs } \\
\text { ional }\end{array}$ & 2.760 .000 & 3.600 .000 & 2.976 .480 & 2.760 .000 & 3.600 .000 & 2.976 .480 \\
\hline $\begin{array}{l}\text { Jumlah } \\
\text { Penghasilan } \\
\text { Bruto }\end{array}$ & 51.360 .000 & 62.688 .000 & 104.798 .280 & 51.360 .000 & 62.688 .000 & 104.798 .280 \\
\hline $\begin{array}{l}\text { Jumlah } \\
\text { Pengurang } \\
\end{array}$ & 4.365 .600 & 5.328 .480 & 8.907 .852 & 4.365 .600 & 5.328 .480 & 8.907 .852 \\
\hline $\begin{array}{l}\text { Jumlah } \\
\text { Penghasilan } \\
\text { Neto }\end{array}$ & 46.944 .400 & 57.359 .520 & 95.890 .428 & 46.944 .400 & 57.359 .520 & 95.890 .428 \\
\hline $\begin{array}{l}\text { Masa Perolehan } \\
\text { Penghasilan } \\
\text { (bulan) }\end{array}$ & 12 & 12 & 12 & 12 & 12 & 12 \\
\hline $\begin{array}{l}\text { Jumlah } \\
\text { Penghasilan } \\
\text { Neto Setahun }\end{array}$ & 46.944 .400 & 57.359 .520 & 95.890 .428 & 46.944 .400 & 57.359 .520 & 95.890 .428 \\
\hline Jumlah PTKP & 24.300 .000 & 26.325 .000 & 28.350 .000 & 36.000 .000 & 39.000 .000 & 42.000 .000 \\
\hline PKP & 22.644 .400 & 31.034 .520 & 67.540 .428 & 10.994 .400 & 18.359 .520 & 53.890 .428 \\
\hline PPh 21 Terutang & 95.558 & 129.313 & 427.583 & 45.808 & 76.498 & 256.958 \\
\hline
\end{tabular}

Sumber: Data Perhitungan PPh Pasal 21 Karyawan Koprasi Telekomunikasi

Selular Sorong 2014 menurut undang - undang (diolah)

Berdasarkan beberapa contoh hasil perhitungan Pajak Penghasilan Pasal 21 Karyawan antara perhitungan menurut perusahaan dan perhitungan menurut undang-undang diketemukan adanya perbedaan hasil perhitungan. Perbedaan hasil dari perhitungan secara keseluruhan tersebut menimbulkan selisih jumlah dari besarnya Pajak Penghasilan Pasal 21 Karyawan yang rata-rata perhitungan perusahaan lebih besar jumlahnya bila dibandingkan dengan hasil perhitungan menurut undang-undang. Dari hasil rekapitulasi data terhadap selisih jumlah pembayaran Pajak Penghasilan Pasal 21 Karyawan antara perhitungan menurut perusahaan dan perhitungan yang berdasarkan undang-undang dapat disajikan sebagaimana Tabel 4.5 berikut ini: 
Tabel 4.5

Selisih Pembayaran PPh Pasal 21 Menurut Perusahaan dan Undang-Undang tahun 2014

\begin{tabular}{|c|c|c|c|c|}
\hline No. & Nama Pegawai & $\begin{array}{l}\text { Perhitungan PPh } 21 \\
\text { (Perusahaan) }\end{array}$ & $\begin{array}{c}\text { Perhitungan PPh } 21 \\
\text { (Undang-Undang) }\end{array}$ & Selisih \\
\hline 1. & Eko Retno Diyah & Rp. 159.950,00 & Rp. 129.313,00 & Rp. $\quad 30.637,00$ \\
\hline 2. & I.Kadek Agus & Rp. 145.852,00 & Rp. $107.975,00$ & $\begin{array}{ll}\text { Rp. } & 37.877,00 \\
\end{array}$ \\
\hline 3. & Gukben Sitanggang & Rp. $646.463,00$ & Rp. $489.658,00$ & Rp. $156.805,00$ \\
\hline 4. & Moch. Soleh & Rp.341.188,00 & Rp. 311.803,00 & $\begin{array}{ll}\text { Rp. } & 29.385,00 \\
\end{array}$ \\
\hline 5. & Azis Mustofa & Rp. 232.944,00 & Rp. $178.388,00$ & $54.556,00$ \\
\hline 6. & Apriadi Heru & Rp. 231.730,00 & Rp. $194.988,00$ & Rp. $\quad 36.742,00$ \\
\hline 7. & Budi Suwito & Rp. $335.409,00$ & Rp. 427.583,00 & Rp. $\quad(92.174,00)$ \\
\hline 8. & Sargimin & Rp. $160.837,00$ & Rp. $121.683,00$ & Rp. $\quad 39154,00$ \\
\hline 9. & Erwin Setyadi & Rp. 214.790,00 & Rp. $171.050,00$ & $43.740,00$ \\
\hline 10. & Prio Sudarmo & Rp. $177.782,00$ & Rp. $145.625,00$ & $32.157,00$ \\
\hline 11. & Andi Rivai Hane & Rp. $52.450,00$ & Rp. $39.388,00$ & $13.062,00$ \\
\hline 12. & Ferry Siswanto & Rp. $47.452,00$ & Rp. 34.813,00 & $12.639,00$ \\
\hline 13. & Imam Munaji & Rp. $180.782,00$ & Rp. $139.933,00$ & $40.849,00$ \\
\hline 14. & Gunawan & Rp. 166.740,00 & Rp. 127.088,00 & $39.652,00$ \\
\hline 15. & M. Gholif & Rp. $214.790,00$ & Rp. $171.050,00$ & $43.740,00$ \\
\hline 16. & Achmad Ghofur & Rp. $157.850,00$ & Rp. $127.388,00$ & $30.462,00$ \\
\hline 17. & Benedictus Heri & Rp. $166.740,00$ & Rp. 129.588,00 & $37.152,00$ \\
\hline 18. & Suprihadi & Rp. 133.150,00 & Rp. $96.350,00$ & $36.800,00$ \\
\hline 19. & Suwarto & Rp. $112.750,00$ & Rp. $94.588,00$ & $18.162,00$ \\
\hline 20. & Agus Sugianto & Rp. 231.730,00 & Rp. 203.425,00 & $\begin{array}{ll}\text { Rp. } & 28.305,00 \\
\end{array}$ \\
\hline 21. & Adi Utomo & Rp. 335.409,00 & Rp. 427.583,00 & Rp. $(92.174,00)$ \\
\hline 22. & Tan Siau Hong & Rp. $100.750,00$ & $\begin{array}{lr}\text { Rp. } 83.579,00 \\
\end{array}$ & $\begin{array}{ll}\text { Rp. } & 17.171,00 \\
\end{array}$ \\
\hline 23. & Denny Trianto & Rp. $105.852,00$ & Rp. $88.250,00$ & $17.602,00$ \\
\hline 24. & Arif Syaifudin & Rp. $97.750,00$ & Rp. $80.833,00$ & $16.917,00$ \\
\hline 25. & Bangun Setyo & Rp. $101.750,00$ & Rp. $84.496,00$ & $17.254,00$ \\
\hline 26. & Mariana Sanga & Rp. $105.852,00$ & Rp. $88.250,00$ & $\begin{array}{ll}\text { Rp. } & 17.602,00 \\
\end{array}$ \\
\hline 27. & Edi Suryono & Rp. $289.940,00$ & Rp. 328.083,00 & Rp. $\quad(38.098,00)$ \\
\hline 28. & Agus Hidayatno & Rp. 213.532,00 & Rp. 178.338,00 & $\begin{array}{ll}\text { Rp. } & 35.144,00 \\
\end{array}$ \\
\hline 29. & Dhian Astuti & Rp. 214.790,00 & Rp. 171.050,00 & $43.740,00$ \\
\hline 30. & Supraptitiyati & Rp. $157.850,00$ & Rp. $127.388,00$ & $30.462,00$ \\
\hline 31. & Nurlaela Dimyati & Rp. $166.740,00$ & Rp. 127.088,00 & $39.652,00$ \\
\hline 32. & Dewi Pratika Damayanti & Rp. $133.150,00$ & Rp. $96.350,00$ & $36.800,00$ \\
\hline 33. & Widodo & Rp. $112.750,00$ & Rp. $94.588,00$ & $18.162,00$ \\
\hline 34. & Hemi Margiyanti & Rp. 231.730,00 & Rp. 194.988,00 & Rp. $\quad 36.742,00$ \\
\hline 35. & Esti Listyowati & Rp. 335.409,00 & Rp. 427.583,00 & Rp. $\quad(92.176,00)$ \\
\hline 36. & Estiyani & Rp. $100.750,00$ & Rp. $83.579,00$ & $\begin{array}{ll}\text { Rp. } & 17.171,00 \\
\end{array}$ \\
\hline 37. & Tri Riswanti & Rp. $105.852,00$ & Rp. $88.250,00$ & $17.602,00$ \\
\hline 38. & Sarwoko & Rp. 214.790,00 & Rp. 171.050,00 & $43.740,00$ \\
\hline 39. & Dini Nurul Hayati & Rp. $214.790,00$ & Rp. $171.050,00$ & $43.740,00$ \\
\hline 40. & Sumiyarsih & Rp. $177.782,00$ & Rp. 145.625,00 & $32.157,00$ \\
\hline 41. & Tutut Hermayati & Rp. $52.450,00$ & Rp. 39.388,00 & $13.062,00$ \\
\hline 42. & Tri Yuli Setyowati & Rp. $47.452,00$ & Rp. $34.813,00$ & $\begin{array}{ll}\text { Rp. } & 12.639,00 \\
\end{array}$ \\
\hline \multicolumn{2}{|c|}{$\begin{array}{c}\text { Jumlah } \\
\end{array}$} & Rp. $7.820 .864,00$ & Rp. 6.773.879,00 & Rp. 1.046.967,00 \\
\hline
\end{tabular}

Sumber : $\quad$ Data selisih bayar PPh Pasal 21 Karyawan Koperasi Telekomunikasi

Selular Sorong tahun 2014(diolah) 
Tabel 4.6

Selisih Pembayaran PPh Pasal 21 Menurut Perusahaan dan Undang-Undang Tahun 2015

\begin{tabular}{|c|c|c|c|c|}
\hline No. & Nama Pegawai & $\begin{array}{l}\text { Perhitungan PPh } 21 \\
\text { (Perusahaan) }\end{array}$ & $\begin{array}{c}\text { Perhitungan PPh } 21 \\
\text { (Undang-Undang) }\end{array}$ & Selisih \\
\hline 1. & Eko Retno Diyah & Rp. 116.700,00 & Rp. $76.500,00$ & $\begin{array}{ll}\text { Rp. } & 40.200,00 \\
\end{array}$ \\
\hline 2. & I.Kadek Agus & Rp. $102.752,00$ & Rp. $51.100,00$ & $\begin{array}{ll}\text { Rp. } & 50.652,00 \\
\end{array}$ \\
\hline 3. & Gukben Sitanggang & Rp. 306.102,00 & Rp. 314.058,00 & Rp. $\quad(7.956,00)$ \\
\hline 4. & Moch. Soleh & Rp. 241.109,00 & Rp. 190.013,00 & $\begin{array}{ll}\text { Rp. } & 51.056,00 \\
\end{array}$ \\
\hline 5. & Azis Mustofa & Rp. $164.782,00$ & Rp. $125.525,00$ & Rp. $\quad 39.257,00$ \\
\hline 6. & Apriadi Heru & Rp. $182.980,00$ & Rp. $142.175,00$ & Rp. $\quad 36.742,00$ \\
\hline 7. & Budi Suwito & Rp. 286.659,00 & Rp. 256.958,00 & $29.701,00$ \\
\hline 8. & Sargimin & Rp. 112.087,00 & Rp. $64.808,00$ & $47.279,00$ \\
\hline 9. & Erwin Setyadi & Rp. 166.040,00 & Rp. 114.175,00 & $51.865,00$ \\
\hline 10. & Prio Sudarmo & Rp. $129.032,00$ & Rp. $92.813,00$ & $36.219,00$ \\
\hline 11. & Imam Munaji & Rp. 132.032,00 & Rp. $83.058,00$ & $48.974,00$ \\
\hline 12. & Gunawan & Rp. $117.990,00$ & Rp. $70.213,00$ & $47.777,00$ \\
\hline 13. & M. Gholif & Rp. $166.040,00$ & Rp. $141.175,00$ & $24.865,00$ \\
\hline 14. & Achmad Ghofur & Rp. $109.100,00$ & Rp. $74.575,00$ & $34.525,00$ \\
\hline 15. & Benedictus Heri & Rp. $117.990,00$ & Rp. $72.683,00$ & $45.307,00$ \\
\hline 16. & Suprihadi & Rp. $84.400,00$ & Rp. $39.475,00$ & $44.925,00$ \\
\hline 17. & Suwarto & Rp. $\quad 64.000,00$ & Rp. $45.808,00$ & $18.192,00$ \\
\hline 18. & Agus Sugianto & Rp. $182.980,00$ & Rp. $154.675,00$ & $28.305,00$ \\
\hline 29. & Adi Utomo & Rp. $286.659,00$ & Rp. $256.958,00$ & $29.701,00$ \\
\hline 20. & Tan Siau Hong & Rp. $52.000,00$ & Rp. $34.829,00$ & $17.171,00$ \\
\hline 21. & Denny Trianto & $\begin{array}{ll}\text { Rp. } & 57.000,00 \\
\end{array}$ & Rp. $39.500,00$ & $17.500,00$ \\
\hline 22. & Arif Syaifudin & $\begin{array}{ll}\text { Rp. } & 49.000,00 \\
\end{array}$ & Rp. $32.083,00$ & $16.917,00$ \\
\hline 23. & Bangun Setyo & Rp. $53.000,00$ & Rp. $35.746,00$ & $17.254,00$ \\
\hline 24. & Mariana Sanga & Rp. $57.102,00$ & Rp. $39.500,00$ & $17.602,00$ \\
\hline 25. & Edi Suryono & Rp. 241.190,00 & Rp. $195.438,00$ & $45.752,00$ \\
\hline 26. & Agus Hidayatno & Rp. $164,782,00$ & Rp. $125.525,00$ & $39.275,00$ \\
\hline 27. & Dhian Astuti & Rp. $166.040,00$ & Rp. $114.175,00$ & $51.865,00$ \\
\hline 28. & Supraptitiyati & Rp. $109.100,00$ & Rp. $74.575,00$ & $34.525,00$ \\
\hline 39. & Nurlaela Dimyati & Rp. $117.990,00$ & Rp. $70.213,00$ & $47.777,00$ \\
\hline 30. & Dewi Pratika Damayanti & Rp. $84.400,00$ & Rp. $39.475,00$ & $\begin{array}{ll}\text { Rp. } & 44.925,00 \\
\end{array}$ \\
\hline 31. & Widodo & Rp. 199.000,00 & Rp. $45.808,00$ & Rp. $153.192,00$ \\
\hline 32. & Hemi Margiyanti & Rp. $182.979,00$ & Rp. $142.175,00$ & $\begin{array}{ll}\text { Rp. } & 40.804,00 \\
\end{array}$ \\
\hline 33. & Esti Listyowati & Rp. 286.659,00 & Rp. 256.958,00 & $29.701,00$ \\
\hline 34. & Estiyani & Rp. $52.000,00$ & Rp. $34.829,00$ & $17.171,00$ \\
\hline 35. & Tri Riswanti & Rp. $57.102,00$ & Rp. $39.500,00$ & $17.602,00$ \\
\hline 36. & Sarwoko & Rp. 116.040,00 & Rp. 114.175,00 & $1.865,00$ \\
\hline 37. & Dini Nurul Hayati & Rp. 166.040,00 & Rp. 114.175,00 & $\begin{array}{ll}\text { Rp. } & 51.865,00 \\
\end{array}$ \\
\hline 38. & Sumiyarsih & Rp. 129.032,00 & Rp. $92.813,00$ & $\begin{array}{ll}\text { Rp. } & 36.219,00 \\
\end{array}$ \\
\hline \multicolumn{2}{|c|}{ Jumlah } & Rp. 5.048.760,00 & Rp. 3.652.255,00 & Rp. 1.396.505,00 \\
\hline
\end{tabular}

Sumber : $\quad$ Data selisih bayar PPh Pasal 21 Karyawan Koperasi Telekomunikasi

Selular Sorong tahun 2015 (diolah)

Tabel di atas menunjukkan data hasil penghitungan Pajak Penghasilan Pasal 21 yang harus dipotong untuk masing-masing pegawai di Koperasi Telekomunikasi Selular (KISEL) Cabang Sorong tahun 2014 menurut perusahaan sebesar Rp. 7.820.864,- (tujuh juta delapan ratus dua puluh ribu delapan ratus enam puluh empat rupiah) dan menurut undang-undang sebesar Rp. 6.773.879,- (enam juta tujuh ratus tujuh puluh tiga ribu delapan ratus tujuh uluh Sembilan rupiah) sedangkan tahun 2015 menurut perusahaan sebesar Rp. 5.048.760,(lima juta empat puluh delapan ribu tujuh ratus enam puluh rupiah) dan menurut undang-undang sebesar Rp. 3.652.255,- (tiga juta enam ratus lima puluh dua ribu dua ratus lima puluh lima rupiah)dengan jumlah selisih masing - masing secara keseluruhan yaitu 
tahun 2014 Rp. 1.046.967,- (satu juta empat puluh enam ribu Sembilan ratus enam puluh tujuh rupiah) dan tahun 2015 Rp. 1.396.505,- (satu juta tiga ratus Sembilan puluh enam ribu lima ratus lima rupiah), yang selanjutnya dalam hal ini pemotong pajak yaitu Koperasi Telekomunikasi Selular (KISEL) Cabang Sorong menyetorkan pajak menggunakan Surat Setoran Pajak (SSP) yang terisi dengan benar, lengkap, dan jelas.

Pajak Penghasilan Pasal 21 untuk setiap Masa Pajak wajib disetor ke Kontor Pos atau Bank Papua yang telah ditunjuk oleh Menteri Keuangan dan penyetoran pajak tidak lebih dari tanggai 10 (sepuluh) bulan berikutnya.

Data dapat diperoleh dengan melihat dokumen (Surat Setoran Pajak) untuk setiap Masa Pajak selama Tahun Pajak 2014. Data yang dijadikan sampel ini merupakan SSP untuk Masa Pajak Januari Tahun Pajak 2014 sampai Masa Pajak Desember Tahun Pajak 2014 dan Masa Pajak Januari Tahun Pajak 2015 sampai Masa Pajak Desember Tahun Pajak 2015.

Berikut waktu dan tempat penyetoran Pajak Penghasilan Pasal 21 yang dilakukan Kisel Cabang Sorong disajikan pada Tabel di bawah ini:

Tabel 4.7

Waktu dan Tempat Penyetoran SSP Oleh Koperasi Telekomunikasi Selular Cabang Sorong (KISEL)

\begin{tabular}{|c|l|l|l|l|}
\hline No. & Masa Pajak & \multicolumn{1}{c|}{ Waktu } & \multicolumn{1}{c|}{ Waktu } & \multicolumn{1}{c|}{ Tempat Penyetoran } \\
\hline 1. & Januari & 3 Februari & 9 Februari & BPD Bank Papua Cabang Sorong \\
\hline 2. & Februari & 3 Maret & 9 Maret & BPD Bank Papua Cabang Sorong \\
\hline 3. & Maret & 2 April & 9 April & BPD Bank Papua Cabang Sorong \\
\hline 4. & April & 2 Mei & 6 Mei & BPD Bank Papua Cabang Sorong \\
\hline 5. & Mei & 2 Juni & Juni & BPD Bank Papua Cabang Sorong \\
\hline 6. & Juni & 2 Juli & 6 Juli & BPD Bank Papua Cabang Sorong \\
\hline 7. & Juli & 4 Agustus & 4 Agustus & BPD Bank Papua Cabang Sorong \\
\hline 8. & Agustus & 2 September & 4 September & BPD Bank Papua Cabang Sorong \\
\hline 9. & September & 2 Oktober & 2 Oktober & BPD Bank Papua Cabang Sorong \\
\hline 10. & Oktober & 3 November & 9 November & BPD Bank Papua Cabang Sorong \\
\hline 11. & November & 1 Desember & 7 Desember & BPD Bank Papua Cabang Sorong \\
\hline 12. & Desember & 2 Desember & 7 Desember & BPD Bank Papua Cabang Sorong \\
\hline
\end{tabular}

Sumber: Penyetoran Pajak Penghasilan Pasal 21 OlehKoperasi Telekomunikasi

Selular Cabang Sorong (KISEL) Tahun 2014 dan 2015

Tabel di atas menunjukkan penyetoran Pajak Penghasilan Pasal 21 oleh Koperasi Telekomunikasi Selular Cabang Sorong (KISEL) yang selanjutnya dievaluasi sesuai dengan Peraturan Direktur Jenderal Pajak Nomor PER-31/PJ/2012 untuk pengisian SSP, waktu, dan tempat penyetoran SSP. Selanjutnya Koperasi Telekomunikasi Selular Cabang Sorong (KISEL) harus melaporkan penyetoran pajak dengan menggunakan Surat Pemberitahuan (SPT) yang terisi dengan benar, lengkap, dan jelas.Pelaporan pajak dapat disampaikan ke Kantor Direktorat Jenderal Pajak atau tempat lain yang ditetapkan oleh Direktur Jenderal Pajak dan pelaporan pajak tidak lebih dari tanggai 10 (sepuluh) bulan takwin berikutnya.

\section{Pencatatan Akuntansi Pada Koperasi Telekomunikasi Selular Cabang Sorong}

Adapun Koperasi Telekomunikasi Selular Cabang Sorong melakukan pencatatan akuntansi yang dilakukan oleh bagian administrasi. Pencatatan akuntansinya adalah sebagai berikut :

\section{Jurnal Tahun 2014}

a. Pada waktu pemotongan gaji karyawan

Beban gaji Rp. 180.612 .000

Hutang gaji $\quad$ Rp. 173.838.121

PPH yang terutang pasal $21 \quad$ Rp. $\quad 6.773 .879$

b. Pada waktu pembayaran gaji karyawan (saat akhir bulan)
Hutang gaji
Rp. 173.838.121

Kas

Rp. 173.838 .121

c. Pada waktu pembayaran $\mathbf{P P h}$ karyawan

PPhterutang pasal $21 \quad$ Rp. $\quad 6.773 .879$

Kas

Rp. $\quad 6.773 .879$ 


\section{d. Jurnal koreksi atas selisih PPh Pasal 21 -} Restitusi

pada waktu pengembalian ke perusahaan :

Kas

Rp. $\quad 1.046 .976$

Hutang gaji

Rp. $\quad 1.046 .976$

pada waktu pengembalian kepada karyawan :

Hutang gaji

Rp. $\quad 1.046 .976$

Kas

Rp. $\quad 1.046 .976$

\section{Jurnal Tahun 2015}

a. Pada waktu pemotongan gaji karyawan

Beban gaji

Rp. 170.982.000

Hutang gaji

Rp. 167.329 .745

PPH terutang pasal $21 \quad$ Rp. 3.652 .255

b. Pada waktu pembayaran gaji karyawan (saat akhir bulan)

Hutang gaji

Rp. 167.329.745

Kas

Rp. 167.329 .745

c. Pada waktu pembayaran PPh karyawan

PPh terutang pasal $21 \quad$ Rp. 3.652 .255
Kas
Rp. $\quad 3.652 .255$

d. Jurnal koreksi atas selisih PPh Pasal 21 Restitusi

pada waktu pengembalian ke perusahaan :

Kas

Rp. $\quad 1.396 .505$

Hutang gaji Rp. 1.396 .505

pada waktu pengembalian kepada karyawan :

$\begin{array}{lll}\text { Hutang gaji } & \text { Rp. } & 1.396 .505\end{array}$

Kas Rp. 1.396 .505

Pembahasan terhadap penghitungan dan pelaporan Pajak Penghasilan Pasal 21 Pada Karyawan

a. Evaluasi Penghitungan Pajak Penghasilan Pasal 21 Karyawan

Setelah dilakukan evaluasi terhadap penghitungan Pajak penghasilan Pasal 21 Karyawan tersebut, diketahui bahwa penghitungan yang dilakukan oleh pihak perusahaan terdapat kesalahan penghitungan. Kesalahan tersebut sebagaimana dalam contoh, setelah dilakukan penghitungan ulang dan dicocokkan dengan hasil penghitungan pajak penghasilan menurut undang-undang adanya ketidak sesuaian dalam penghitungan. Ketidak sesuaian sebagaimana dimaksud terdapat dalam penghitungan pada 42 karyawan tetap Koperasi Telekomunikasi Selular (KISEL) Cabang Sorong.

Kesalahan yang terjadi pada proses perhitungan pemotongan $\mathrm{PPh}$ Pasal 21 pada gaji pegawai mengakibatkan jumlah pajak yang disetor menjadi lebih besar daripada yang seharusnya. Dari kelebihan pembayaran pajak tersebut, setelah dilakukan klarifikasi dengan Kantor Dirjen Perpajakan Kota Sorong, kelebihan pembayaran telah dikembalikan kepada pihak Koperasi Telekomunikasi Selular (KISEL) Cabang Sorong dan selanjutnya dikembalikan kepada para karyawan yang berhak menerimanya.

\section{b. Evaluasi Pelaporan Pajak Penghasilan Pasal 21 Karyawan.}

Dalam hal pengisian bangko formulir pembayaran, berdasarkan hasil pengamatan pada Surat Setoran Pajak untuk Masa Pajak JanuariDesember 2014 dan 2015, Koperasi Telekomunikasi Selular (KISEL) Cabang Sorong telah melakukan pengisian dan penulisan SSP dengan tepat dan pengisian yang dilakukan oleh Koperasi Telekomunikasi Selular (KISEL) Cabang Sorong telah benar, lengkap, dan jelas. Selain itu, Pajak Penghasilan Pasal 21 telah disetorkan ke Bank yang ditunjuk oleh Menteri Keuangan yaitu Koperasi Telekomunikasi Selular (KISEL) Cabang Sorong menyetorkan ke Bank BPD PAPUA Cabang Kota Sorong dan disetorkan tepat waktu yaitu tidak lebih dari tanggai 10 (sepuluh) bulan berikutnya.

\section{KESIMPULAN DAN SARAN Kesimpulan}

Berdasarkan hasil analisis data dan pembahasan yang telah dilakukan pada Koperasi Telekomunikasi Selular (KISEL) Cabang Sorong, maka dapat ditarik kesimpulan sebagai berikut:

1. Koperasi Telekomunikasi Selular (KISEL) Cabang Sorong sudah benar dalam melakukan mekanisme pelaporan serta pembukuan $\mathrm{PPh}$ Pasal 21 akan tetapi perusahaan belum mampu melakukan perhitungan pemotongan dan penyetoran Pajak Penghasilan Pasal 21 yang sesuai dengan undang - undang perpajakan.

2. Koperasi Telekomunikasi Selular (KISEL) Cabang Sorong diharapkan lebih memahami undang - undang perpajakan khususnya PPh Pasal 21 serta harus selalu up to date mengenai perkembangan ketentuan perpajakan yang berlaku, mengingat peraturan perundang undangan perpajakan yang berlaku di Indonesia sering mengalami perubahan sesuai dengan situasi dan kondisi mengikuti perkembangan social dan ekonomi sehingga tidak akan terjadi lagi kesalahan perhitungan pajak terutang yang menyebabkan kerugian bagi karyawan , perusahaan maupun Negara. Dalam hal ini pihak 
pemotong pajak Koperasi Telekomunikasi Selular (KISEL) Cabang Sorong.

\section{Saran}

Berdasarkan hasil pembahasan dan kesimpulan di atas, maka ada beberapa saran yang diharapkan akan memberikan manfaat:

1. Melihat kesalahan yang sering terjadi pada proses perhitungan $\mathrm{PPh}$ pasal 21 pada gaji pegawai khususnya pada perhitungan dan pemotongan maka, peneliti memberikan solusi terhadap manajemen Koperasi Telekomunikasi Selular (KISEL) Cabang Sorong agar membetulkan rumus perhitungan PPh Pasal 21 sesuai dengan Undang-Undang Perpajakan sehingga tidak merugikan karyawan. Selain itu,

2. Koperasi Telekomunikasi Selular (KISEL) Cabang Sorong harus lebih tanggap dalam masalah pelaporan pajak yang terjadi pada kasus ini, sehingga Koperasi Telekomunikasi Selular Cabang Sorong (KISEL) tetap dapat melaporkan Pajak Penghasilan Pasal 21. Untuk masalah pelaporan pajak, Koperasi Telekomunikasi Selular Cabang Sorong (KISEL) dapat menerapkan peraturan terbaru yaitu Peraturan Menteri Keuangan Nomor: 91/PMK.03/2015 tentang Pengurangan atau Penghapusan Sanksi Administrasi atas Keterlambatan Penyampaian Surat Pemberitahuan, Pembetulan Surat Pemberitahuan, dan Keterlambatan Pembayaran atau Penyetoran Pajak.

3. Diharapkan Koperasi Telekomunikasi Selular (KISEL) Cabang Sorong tetap malakukan kewajibannya untuk melaksanakan pemotongan, penyetoran sebelum jatuh tempo yang telah ditentukan.

\section{DAFTAR PUSTAKA}

Anonim $^{1}$.www.kiselindonesia.com

Anonim $^{2} . \underline{\text { www.online-pajak.com }}$

Anonim $^{3}$. www.pajak.go.id

Mardiasmo Dr.,MBA. Ak. (2009). Perpajakan Edisi Revisi 2009. Yogyakarta:Penerbit Andi.

S. Munawir, (1985). Pokok- Pokok Perpajakan. Yogyakarta: Penerbit Liberty.

Hasanuddin Tatang \& Widyaiswara, (2015). Perpajakan Bendahara Pengeluaran.
Jakarta: UNDP.

\begin{tabular}{ccr} 
Kementerian Keuangan Republik Indonesia, & \multicolumn{2}{r}{ In } \\
Direktorat & Penyuluhan, Pelayanan & dan \\
Hubungan & Masyarakat, $P P h$ & Pajak \\
Penghasilan. Google Play Book &
\end{tabular}

